\title{
Identity between Languages: The Case of Spanglish in Short Narratives
}

\author{
I am my language. (Anzaldúa 2012, 81)
}

We are what we speak. (Pérez Firmat 2003, 2)

\begin{abstract}
This article analyses the role of Spanglish in short narratives to evaluate its use within the process of identity construction. For this purpose, three short stories were chosen: Sandra Cisneros's "Woman Hollering Creek,” Aurora Levins Morales's “A Remedy for Heartburn,” and Rosario Morales's "Cosecha.” Studied as a linguistic phenomenon, the Spanglish present in these works illustrates how individual and cultural identities of writers and characters are defined by language.
\end{abstract}

Keywords: Aurora Levins Morales, identity, Latin American short narratives, Rosario Morales, Sandra Cisneros, Spanglish

The language (or languages) that a person speaks is an inherent part of his/her identity. As the Cuban-American writer Gustavo Pérez Firmat states, "the language that we speak is a fundamental component of our nationality, and hence of our sense of who we are [...]. We are what we speak” $(2003,2)$. Reflecting on the quotation and supporting the view of a merger between language and identity, the purpose of this article is to analyse the role of Spanglish in short narratives in order to evaluate the presence and use of this linguistic phenomenon within the process of identity construction.

For this study, three short stories were selected: Sandra Cisneros's "Woman Hollering Creek," published in the book Woman Hollering Creek and Other Stories, and Aurora Levins Morales's “A Remedy for Heartburn” and Rosario Morales's "Cosecha," both published in the book Cosecha and Other Stories. It is important to point out that Woman Hollering Creek and Other Stories (1991) by Sandra Cisneros, and Cosecha and Other Stories (2014) by Rosario Morales and her daughter Aurora Levins Morales, were published more than twenty years apart. However, the Spanglish used in these works by their respective writers is very similar in terms of form, presence, and symbolism. Languages evolve, and Spanglish is evolving and will continue to evolve, yet the Spanglish terms seen in these stories are words and expressions still in use today. 
The premise of this article is the idea that the individual and cultural identities of the writers or of their characters are expressed through the Spanglish present in the works. In regard to these writers and their respective backgrounds, it is important to point out that Cisneros was born in the United States, but during her youth she and her family constantly migrated between the United States and Mexico. Rosario Morales was born in the United States, but her parents were both from Puerto Rico. Her daughter, Aurora Levins Morales, was born in Puerto Rico but was raised in the United States. One can see how, in the three writers, there is the bicultural issue of being in between two cultures and two languages. That is why it is not surprising to find Spanglish in their literary works. Taking this perspective into consideration, it is important now to explore the term "Spanglish" before analysing their narratives.

\section{Spanglish: Definitions and perspectives}

Spanglish can be defined as the combination of Spanish and English, and is commonly found in the United States, in areas where there is a large number of Spanish speakers and where the two languages come into contact (Ardila 2005, 63). However, the combination of Spanish and English can be found in one way or another not only in the United States but also in Spanish-speaking countries or communities where English is also spoken. Ilan Stavans tells us that Spanglish is found "in the Spanish-speaking world as well, from Madrid to Bogotá and Ciudad Juarez. According to newspaper reports, echoes of Spanglish have been heard even in the Patagonia" (2008, ix-x). Spanglish may be as simple as using a word of Spanish when one speaks English, or a word of English when one speaks Spanish. Spanglish may also be far more complex, as when verbs and nouns are created in Spanish from English, and when grammatical structures of English are used in Spanish.

Alfredo Ardila points out that the Hispanic population of the United States is approximately $12 \%$ of the total population of that country. These Hispanics have their origins not only in the United States but also in Mexico, Central and South America, and Puerto Rico, as well as other areas (Ardila 2005, 62). This mixture of Spanish-speakers from different origins, combined with different levels of proficiency in both Spanish and English, creates interesting linguistic realities in the United States. There are Spanish-speakers who can barely speak any English. There are Hispanics who can hardly speak any Spanish. There are perfectly bilingual Spanish/English speakers, too. In fact, these different combinations of speakers of Spanish and English, with their different abilities to speak 
each language, in the United States are what help to create the "interlanguage" of Spanglish (Ardila 2005, 63). Ardila also declares that, since Spanglish is not a "unified dialect" and since it presents so many variations and differences from place to place (New York, Texas, California, and Florida), it cannot be considered a real language $(2005,63)$. Ricardo Otheguy and Nancy Stern, for their part, say that the term "Spanglish" should not even be used. They maintain that considering Spanglish to be a language in its own right implies that Hispanics in the United States do not speak standard Spanish, which excludes them from speaking a "genuine" world language, and this marginalizes them (Otheguy and Stern 2011, 85).

Whether or not Spanglish can be considered a language in its own right remains debatable; however, Spanglish does have structure. The Chicano Spanish of the south-western United States, as it diverges from standard Spanish, presents structured, consistent transformations in phonetic aspects such as vowel and consonant changes, and in grammatical issues such as verb tenses of the indicative mood and the subjunctive mood, personal pronouns, and even nouns, adjectives, and adverbs (Sánchez 2008, 12-29). In her research, Ana Celia Zentella (2008) also shows how the Spanish spoken among Puerto Rican children, which differs from standard Spanish, is organized and presents a structured grammar.

Jason Rothman and Amy Beth Rell consider that Spanglish is neither good nor bad, and that one cannot condemn Spanglish without condemning its sources. These critics state that "Spanglish is no better or worse than its constituent parts: Spanish and English. That is, if it serves the function of communication and is rule governed; it's quite simply a language" $(2005,516)$. Some scholars, such as Roberto González Echevarría and Ricardo Otheguy and Nancy Stern believe that Spanglish stereotypes and marginalizes its speakers, resulting in them being perceived as uneducated and incapable of speaking standard Spanish. They think that speaking Spanglish will prevent them from being able to obtain good jobs and fitting into the mainstream United States (Stavans 2008, ix).

\section{Spanish and identity construction}

Gloria Anzaldúa, a Mexican-American writer, defends Spanglish as a linguistic reality and explains how it is a part of her identity as follows:

For a people who are neither Spanish nor live in a country in which Spanish is the first language; for a people who live in a country in which English is the reigning tongue but who are not Anglo; for a people who cannot entirely identify with either standard (formal, Castilian) Spanish nor Standard English, what recourse is left to them but to create their own lan- 
guage? A language which they can connect their identity to, one capable of communicating the realities and values true to themselves - a language with terms that are neither español ni inglés, but both. (Anzaldúa 2012, 77)

Defenders of Spanglish, such as Ilan Stavans and Gloria Anzaldúa, see this linguistic phenomenon as a normal evolution in society and a key part of its speakers' construction of identity. Their language is themselves. Stavans says that the supporters of Spanglish, like himself, "celebrate this hybrid form of communication for its dynamism, creativity, and political savvy" (2008, ix). Anzaldúa, as seen above, considers Spanglish to be a part of her identity, and adamantly defends her language when she says:

\footnotetext{
So, if you want to really hurt me, talk badly about my language. Ethnic identity is twin skin to linguistic identity - I am my language. Until I can take pride in my language, I cannot take pride in myself [...]. Until I am free to write bilingually and to switch codes without having always to translate, while I still have to speak English or Spanish when I would rather speak Spanglish, and as long as I have to accommodate the English speakers rather than having them accommodate me, my tongue will be illegitimate. (Anzaldúa 2012, 81)
}

Anzaldúa is defending her identity by means of language, and her struggle fits the textbook definition of construction of personal identity. As Manuel Castells tells us, "identity is people's source of meaning and experience [...]. By identity, as it refers to social actors, I understand the process of construction of meaning on the basis of a cultural attribute [...]. For a given individual, or for a collective actor, there may be a plurality of identities. Yet, such a plurality is a source of stress and contradiction in both self-representation and social action" $(2011,6)$. Spanglish is an example of precisely this self-representation within a process of communication and social action since its use provides meanings for different cultures and individuals.

\section{Three revealing topics for analysing Spanglish in fiction}

In order to develop the premise of this article, that is, that identity is expressed and represented by Spanglish, three different topics will be considered with which to explore the use and significance of Spanglish. The first topic is food, the second one is the names or expressions used to refer to people, and the third one is the analogy of life as a soap opera or telenovela. These topics are not only to be found in the short stories; all three are also related to the process of the 
construction of identity. In the case of food, we are dealing with a human need; the choices of food and what certain foods are called can disclose interesting elements about the identity traits of characters and writers. In the second case, the names or expressions people use to refer to others are also a very important sign of identity because they show how people perceive others and how relationships are built. The third case, life as a soap opera, exposes a way of escaping reality by following the structure of someone else's fictional life. Indeed, many issues about the conflict between fantasy and reality and what that reveals about the individual self and his/her way of interacting with others can be explored. Let us listen to what the critics say about these three aspects.

In the case of food, as the old adage proclaims, you are what you eat. Food is a part of the identity of a country and even of different ethnic groups or regions in a given nation. In her article "Nuevo Latino: Rebranding Latin American Cuisine," Vanessa Fonseca, a specialist in communications and language science at the University of Costa Rica, explains that ethnic foods from one's "native" culture produce nostalgia for an "imaginary homeland." For example, even if a Mexican American was not born in Mexico, his/her perceived identity may be that of a Mexican, and it can be in essence imaginary, but it is strong. In this sense, food from the "homeland" that a person relates to represents "a sense of belonging" to that homeland (Fonseca 2005, 102). The idea of belonging to a place or a community is key to the process of identity construction. This assertion exposes the relevance of national and cultural identities as well as the individual's desire to be part of a group, and by eating the food in question he/she feels closer to that "imaginary homeland" pointed out by Fonseca. In addition, the ways that food is referred to with different words can also reveal aspects of identity. Where the second topic, names that refer to people and terms of endearment, is concerned, just as we are the language that we speak, and we are what we eat, we are also who we are called. Our names are part of our identity. Meike Watzlawik of Sigmund Freud University in Vienna, Austria, and her colleagues, in their article "First Names as Signs of Personal Identity: An Intercultural Comparison," affirm that our names are an important part of our personal identity when they say that "names stand for the person (object) and trigger associations with that person." They add that our names make us "distinct and distinguishable from others" (Watzlawik et al. 2016, 1). This affirmation illustrates the relationship of the Self and the Other, which need to mutually differentiate who they are because one is different from the other and those differences validate identities.

Turning now to soap operas as scenes of life, the third topic, Alan M. Rubin of Kent State University and Elizabeth M. Perse of the University of Delaware, in their article "Audience Activity and Soap Opera Involvement: A Uses and Effects Investigation," tell us that some viewers of soap operas actually integrate them into 
their lives along with the behaviour of the soap-opera stars, and these viewers also relate to the problems that the stars face in the programmes. It seems that, at least for a while, the identity of the soap-opera star becomes the identity of the viewer (Rubin and Perse 1987, 250, 251). In other words, one can observe vicarious viewers who are part of a process of self-construction in which they are active participants in living others' lives. The TV stars might be their models, and symbolically, living another's life, the viewer forgets about his/her own life or evades the problems or obstacles he/she has to face by living a fake identity. Thus, it is time to consider how these three topics are depicted through the use of Spanglish in the literary works selected, and to see how they contribute to developing the theme of identity. But first let us introduce the plots of each story.

In "Woman Hollering Creek," Sandra Cisneros uses the legend of "La Llorona" symbolically to describe the unhappy life of a young Mexican woman who married a Mexican and moved to the United States. Her husband soon began to beat her, and she did not speak English. She had one child and was pregnant with another before she escaped back to Mexico to get away from her abusive husband and her unhappy life. In “A Remedy for Heartburn,” Aurora Levins Morales uses the image of physical hunger along with the emotional hunger and desire of women, and Latinos in general, to be treated equally in society. Her "remedy" for heartburn is to no longer to "swallow" the social injustices that she is faced with but to fight against them. In "Cosecha," Rosario Morales tells the story of a Puerto Rican mother and her daughter who, living in the United States, return to Puerto Rico to see their dying mother and grandmother respectively one last time.

\section{Food as an indicator of identity}

In "A Remedy for Heartburn," the author uses two Spanglish Anglicisms related to food in order to criticize the repressive culture of the United States towards Hispanics. Levins Morales states that "halfway through each day of hard work and boredom, we stop and have some lonche. Not at home on weekends. We never have lonche at home. But weekdays when we step into some hallway a counter and six red stools and order a sánguich - that's lonche” (Levins Morales 2014, 3; my italics). The American " lunch" and "sandwich" are portrayed here in a disparaging way as a metaphor for a boring life that gives her heartburn.

Another example in this story is the following:

The USDA surplus lunches they served at our grade school comedor were excellent for the immigrant eater's lonche break. The kids used to say the beans tasted of cucaracha, they'd been sitting in the warehouse so long. As for the lukewarm powdered milk we gagged on, it 
was what each of us was told to be grateful for - it would make us strong and healthy - and, if we got good grades and had respect for our elders, it would make us worthy of our citizenship in that great nation los Estados Unidos, where everything good came from. (Levins Morales 2014, 4; my italics)

The irony here is obvious: "cockroach"-tasting beans are found in the United States, and the Spanish version "los Estados Unidos" is also used ironically to express distaste.

Vanessa Fonseca's idea of a national identity related to food is also seen in other food items which are named in Spanish, giving them an exotic flair, a longing for the homeland, and a sense of pride. For example, in "A Remedy for Heartburn," we find "malanga" (Levins Morales 2014, 4) and "yautía" (9), which are both edible tubers. These words appear in Spanish instead of one of the many English equivalents of these words, such as "taro" and "blue taro" or "purple taro." In another example we find "bacalao" (9) instead of "cod" (9). In "Cosecha," we find the Spanish word "guineos" (Morales 2014, 125, 141) instead of the English "bananas" or "plantain," "morcilla” (139) instead of "blood sausage," "yerba buena" (140) instead of "mint," and "tinta de café" (144) instead of "espresso coffee." The use of Spanish words to describe food within an English text provides more strength, flavour, and significance to these items.

Another interesting use of Spanglish to describe food is found in "A Remedy for Heartburn" when Aurora Levins Morales states that she no longer eats death, which means that she no longer passively accepts bad treatment from the society of the United States simply because she is a Hispanic woman. She announces her subversion, and the text corroborates her resolution:

Recently I don't eat death anymore, and I've been doing my piece to change the national diet of Puerto Rico. Death al escabeche, death al fricasé, death frito and death con habichuelas. I've learned a lot of history by now, and I know that at least since Colón, we've always been hungry and dying. Some of us have gotten fierce enough to attack the ones who starve us. (Levins Morales 2014, 9)

The English word "death" represents the culture of the United States and the oppression that comes with it, while preparing food "escabeche" and "fricasé," or the Spanish food items "frito" and "habichuelas," represent the Puerto Rican way. She fights against this oppression by "cooking” food her own way. 


\section{Names and nicknames as identity traits}

The second aspect of Spanglish is seen in the use of the names chosen to refer to different people. A person shows his/her cultural identity by the way he/she refers to his/her family and friends. For example, even if one speaks Spanish and English, one will refer to one's parents with the corresponding name or term that comes from the language or culture to which one is closer, or the one that shows more authenticity. All three of our authors are bilingual, but the way that they choose to refer to people in the stories tells us something about them or the characters they have created. For example, in "Cosecha," one of the main characters, Rebecca, even though she is an American living in the United States, calls her grandmother "buela Pepa." When she thinks of her grandmother, her Hispanic identity overshadows her American side, and she uses a shortened form of "abuela" (grandmother) to refer to her. She also refers to her father as "Papi" in the story. This same idea is seen in "A Remedy for Heartburn" when the bilingual narrator, living in the United States, calls her mother "Mami" and her father "Papi." In sum, terms of endearment are linked to the Spanish language.

The Spanish used in these English texts varies from respectful terms or terms of endearment to condescension and outright insults. At times, certain terms are used in Spanish to praise people or to show respect. These terms of respect, in Spanish, show feelings, the emotion that is being expressed by means of language. In "Woman Hollering Creek," Cleófilas's neighbour is referred to as "señora Dolores" (Cisneros 1991, 47) and not just "Dolores." The word señora "Mrs" is a sign of respect which is very strong in Spanish. In "Cosecha," the grandmother calls her granddaughter "la americanita” (Morales 2014, 123), which is another term of endearment, especially given the suffix -ita. It is more intimate than "the little American." The same grandmother calls another granddaughter "la licenciada" $(129,135)$, which is not so much a term of endearment but rather a term of respect because it recognizes an academic degree and, as Watzlawik et al. affirm, a nickname can be used as a form of social control, status, or even insult $(2016,7)$. Another example can be found in the male character of the soap opera in "Woman Hollering Creek," who calls the female character María "mi querida” (Cisneros 1991, 52) instead of "my darling." For Cisneros, there is more intimacy in the Spanish language, which she chooses to name some of her characters.

The terms of condescension also show emotion that is expressed in Spanish and not in English. Spanish better projects the feelings of the Hispanic speaker. In "Woman Hollering Creek," a female neighbour calls Cleófilas "mi'jita” (Cisneros 1991, 51), which means "my little daughter.” This term is commonly used in Latin America to give advice, but in a scolding manner. It carries more meaning 
and more force than "my daughter." In "Cosecha," a woman calls a younger woman who has no money but who is a good person "Pobrecita" (Morales 2014, 140). She recognizes her economic situation, but the use of the suffix -ita confers sympathy upon her. In "Woman Hollering Creek," Cleófilas realizes that she had been spoiled as a child, being the only daughter in her family, and so she calls herself "the consentida - the princess" (Cisneros 1991, 47). Here, a translation is given in English to help clarify that she was not just spoiled but also pampered as a "princess," which implies not only her perception of being spoiled but also the way she was treated. And, in a moment of despair, pondering how sad her life has become because she is alone, poor, and abused, Cleófilas realizes that she is no longer a princess. Cleófilas then wants to change her identity by imagining a change of her name. She imagines a more poetic name, like that of a jewel. Instead of Cleófilas, she wishes she had a name such as Topazio, Yesenia, Cristal, Adriana, Stefania, or Andrea (53). She wishes for a change of name because, as Watzlawik et al. declare, "the meaning of the name is not static, the individual can re-negotiate his or her identity and with it the meaning of his or her name at any given point in time [...] but also the meaning perceived by others changes" $(2016,3)$. Subconsciously, Cléofilas wants to change her identity for herself and for others.

The terms can also be more negative. In "Cosecha," we find the term "la muchacha” (Morales 2014, 142) between quotation marks, referring to a young woman who had had an abortion. In this context, the term is not used positively because it is generic and denies an identity. She does not deserve a name because of her action. We also find a passage where a girl's cousin always called her "boba" and "sapa," two disparaging terms which mean "foolish" (126), because they did not like her. And when referring to a bad husband, the term "sinvergüenza," meaning "shameless," is used (123). In "Cosecha” we also find "mujer maldita," meaning "damned woman" (126), when a daughter refers to her own mother, whom she did not love. In "Woman Hollering Creek," Felice, a liberated woman who gives Cleófilas a ride to the bus station so she can return to Mexico, criticizes a certain car, saying that it was for "viejas" (Cisneros 1991, 55). A "vieja” is not only a way to call someone an "old woman" but is also an insult. Finally, in "Cosecha," a woman is referred to as "ingrata” (Morales 2014, 142), which literally means "ungrateful," but in Spanish this term is an insult since it is used to designate someone whose actions and behaviour hurt others. The final and worse insult of the story is when one woman insults her relative by calling her "cara de culo," meaning "butt face" (139). Again, these terms are used in Spanish and not in English in order to show more passion and stronger feelings, like those of rage and hatred, which help reveal more identity issues or authentic traits. 


\section{Soap operas as scenes of one's life on TV}

The third category of Spanglish to be analysed in this paper can be visualized in the word telenovela or "soap opera," which is found in "Woman Hollering Creek" and in "A Remedy for Heartburn.” Soap operas offer people an escape from reality, for at least a few hours a week, and they are very popular both in the United States and in Latin America. Alan Rubin and Elizabeth Perse tell us that, when people watch soap operas, they are able to identify with the characters and even feel as if they know them (1987, 248). In "A Remedy for Heartburn" and "Woman Hollering Creek," the terms novela and telenovela are used respectively instead of the English "soap opera." This may be simply for exotic reasons, as seen above, since the term "television novel" is more appealing than that of "soap opera." After all analysing the terms literally - living your own story on television is better than buying soap that will be used to wash dishes and clothing, which is work. The Spanish version of the word represents escape; the English version represents toil.

In "A Remedy for Heartburn," Aurora Levins Morales presents the situation of a Hispanic woman at home, dominated by the culture of the United States. The narrative also presents some possible solutions regarding what she could do to avoid boredom. Some solutions to make her life more exciting are gossiping, religion, having an affair, and starring "in your own novela, playing hourly in the patios and kitchens of your scandalized vecinas" (Levins Morales 2014, 4). By using the Spanish words "novela" and "vecinas" instead of the English "soap opera" and "neighbours," she is in essence including other Hispanics in her soap opera and excluding white Americans. For her, this escape from reality with an imaginary love affair is a Hispanic event that helps diminish the boredom of her life.

In "Woman Hollering Creek," the main character, Cleófilas, is an abused, pregnant woman who speaks no English. She lives in the Unites States with her abusive husband. Lou Lu and Michael Argyle affirm that soap operas are watched for entertainment and to escape one's daily life $(1993,501)$. This is quite clear in the case of Cléofilas, who loves to watch telenovelas and who sees them as a means of escaping from her reality. Cleófilas mentions a soap opera that she likes called Tú o Nadie, which means "You or No One." This soap opera is a mise en abyme for her life. She is alone, helpless, and in many ways a "nobody" in the United States. But she lives her life vicariously through the women in the soap opera. She desires nice clothing like the ones women wear on television, and she compares her husband (unfavourably) to the men in the soap opera. The women in the soap opera are slapped and abused just as she is, and she compares her own reaction to being beaten for the first time to the women's reactions in the soap operas. She did not run away the first time she was beaten, as she imagined 
she would when she saw it on the soap opera for the first time. She always wanted her life to be like a soap opera on television. She wanted real passion, real love like she saw in the soap operas. And in truth, her life is like a soap opera, but with no happy ending in sight. Cleófilas recognizes that her life is like a soap opera only it becomes sadder and sadder, and, as she says, with no commercial breaks in it that would give her a chance to take a break from her sad life.

Spanish and English meet when Cleófilas goes to a doctor's appointment and when the staff notice her bruises. They decide to help her escape back to Mexico, and the woman from the clinic, Graciela, telling a friend about Cleófilas, says: “A regular soap opera sometimes. Que vida, comadre. Bueno bye" (Cisneros 1991, 55; italics in original). Cleófilas has her image of a romanticized, unreal Hispanic version of a telenovela that she is not living, and Graciela sees Cleófilas's life as a real soap opera, that is, a real version of a bad soap opera in the United States. In other words, the reader can visualize different worlds, different perspectives, and different realities in this fictitious world.

\section{Concluding remarks}

In conclusion, identity between languages, as the title of this article calls it, is concretized in the linguistic phenomenon called Spanglish. For some scholars, it is a dialect, for others a true language. In fact, this merger of English and Spanish known as Spanglish does not remain on the linguistic level but expands to include a cultural dimension. It also goes from the individual to the collective, from the self to others, from a subject who is an agent to the subject who is subjected. In fact, the issue of identity is an undeniable element of the cultural dimension, where subjectivity is defined by discourse, and the use of Spanglish helps illustrate this view.

In the case of the literary works that were selected for analysis, one vividly sees the cultural challenges and realities that Hispanic Americans face in the United States. These works also show the linguistic reality that they live in to be in between two languages, a difficult position frequently ignored by mainstream culture in the United States, but one that is, at the same time, an opportunity for them to create their own language and thus their own identity. Taking into account the three topics in the narratives - food, names or ways of addressing people, and telenovelas (soap operas) as life itself - and by exploring their links to the process of subject formation, one sees how languages transform themselves, transform their contexts, and are transformed by them. Thus, one witnesses how subjects are in a constant process of identity construction as they construct or 
reinvent words. In this article, by analysing literary works, we have witnessed how cultural identity, that is, the feeling of belonging to a group because of nationality, ethnicity, or social class, among other elements, demands simultaneously self-conception and social perception, which are transmitted in a mixture of languages exhibiting tension and contradiction, as well as reconciliation. The case of Spanglish is the case of a versatile identity in constant movement, reinventing a language to legitimize a place in our diverse world.

\section{Works cited}

Anzaldúa, Gloria. Borderlands/La Frontera: The New Mestiza. San Francisco: Aunt Lute Books, 2012.

Ardila, Alfredo. "Spanglish: An Anglicized Spanish Dialect." Hispanic Journal of Behavioral Sciences 27.1 (2005): 60-81.

Castells, Manuel. The Power of Identity: The Information Age: Economy, Society, and Culture. Vol. 2. Oxford: Wiley \& Sons, 2011.

Cisneros, Sandra. Woman Hollering Creek and Other Stories. New York: Random House, 1991.

Fonseca, Vanessa. "Nuevo Latino: Rebranding Latin American Cuisine." Consumption, Markets and Culture 8.2 (2005): 95-130.

Lu, Luo, and Michael Argyle. "TV Watching, Soap Opera and Happiness." Kaohsiung Journal of Medical Sciences 9 (1993): 501-507.

Levins Morales, Aurora. "A Remedy for Heartburn." Cosecha and Other Stories. By Rosario Morales and Aurora Levins Morales. Cambridge: Palabrera Press, 2014. 3-10.

Morales, Rosario. "Cosecha." Cosecha and Other Stories. By Rosario Morales and Aurora Levins Morales. Cambridge: Palabrera Press, 2014. 121-147.

Morales, Rosario, and Aurora Levins Morales. Cosecha and Other Stories. Cambridge: Palabrera Press, 2014.

Otheguy, Ricardo, and Nancy Stern. “On So-Called Spanglish.” International Journal of Bilingualism 15.1 (2011): 85-100.

Pérez Firmat, Gustavo. Tongue Ties: Logo-Eroticism in Anglo-Hispanic Literature. New York: Palgrave Macmillan, 2003.

Rothman, Jason, and Amy Beth Rell. "A Linguistic Analysis of Spanglish: Relating Language to Identity." Linguistics \& the Human Sciences 1.3 (2005): 515-536.

Rubin, Alan M., and Elizabeth M. Perse. "Audience Activity and Soap Opera Involvement: A Uses and Effects Investigation." Human Communication Research 14.2 (1987): 246-268.

Sánchez, Rosaura. "Our Linguistic and Social Context." Spanglish. Ed. Ilan Stavans. Westport: Greenwood Press, 2008. 3-41.

Stavans, Ilan. "Preface.” Spanglish. Ed. Stavans. Westport: Greenwood Press, 2008. ix-x.

Watzlawik, Meike, Danilo Silva Guimarăs, Min Han, and Ae Ja Jung. "First Names as Signs of Personal Identity: An Intercultural Comparison.” Psychology \& Society 8.1 (2016): 1-21.

Zentella, Ana Celia. "The Grammar of Spanglish." Spanglish. Ed. Ilan Stavans. Westport: Greenwood Press, 2008. 42-63. 
Andrew Lloyd Smith has master's degrees in French Literature (University of Oregon) and a Diplôme d'Études Approfondies in French as a Foreign Language (Université des Antilles et de la Guyane). He is full professor of French at the National University in Heredia Costa Rica and associate professor at the University of Costa Rica. A native of the United States, he has been a resident of Costa Rica since 1992. 
